\title{
Further Ethical Challenges in Military Science from the Perspective of the Catholic Church: Reflection on the Use of Drones ${ }^{1}$
}

\author{
Lóránd UJHÁZI²
}

The ethical assessment of the appropriate forms of offensive military action have been one of the most significant areas in this respect over the past few years. In the teachings of many religions military weapons and procedures are traditionally evaluated and the limits assessed as to what is appropriate in a war situation. In the Catholic Church quite an elaborate system has been evolved, beginning with the teaching on what constitutes a just war, followed by the medieval criminal law procedures as determined by the councils of the Church, and in the $20^{\text {th }}$ century the various declarations on atomic weapons and weapons of mass-destruction. The Catholic Church still has no established and official position on offensive action in war in the light of the UAV systems. Different opinions and views have been expressed, but it is still far from being a definitive teaching. Research institutes in the Vatican, in the different Episcopal Conferences, and in Military Ordinariate are working on an overall assessment of the problem. However, a comprehensive and correct position has to take political considerations into account, as well as the advantages brought about by technical advances and an assessment of security factors. This way a position can evolve that is faithful to the Catholic Church's tradition, a doctrine what is acceptable to the political leadership, too.

Keywords: Military studies, Catholic Church, Just War, UAV systems

1. A robot may not injure a human being or, through inaction, allow a human being to come to harm.

2. A robot must obey orders given it by human beings except where such orders would conflict with the First Law.

3. A robot must protect its own existence as long as such protection does not conflict with the First or Second Law. ${ }^{3}$

The American science fiction writer, Isaac Asimov was playing around with the idea in the 1940s that there would come a society where robots and humans lived together. As every society, this one also required a rule of coexistence to be laid down. At that time Asimov's

1 The work was created with the support of the Zrínyi Miklós habilitation excellence programme operated by the National University of Public Service in the PACSDOP-2.1.2-CCHOP-15-2016-00001 "Public Service Development Establishing Good Governance” project.

2 Ph.D., Senior Research Fellow, National University of Public Service, Faculty of Military Science and Officer Training; email: ujhazi.lorand@uni-nke.hu.

3 The rules of robotics known from science fiction literature were created by Isaac Asimov. The three rules mentioned were completed with a fourth, more specifically a zeroth one. According to the zeroth, a robot may not injure humanity, or, by inaction, allow humanity to come to harm. The robot is responsible for protecting the whole of humanity. So the robot can harm people if he can do so in service of humanity. 
ethical questions and commentaries belonged to the world of science fiction. Today ethics, law, theology and philosophy all pose similar questions regarding "robots". Machines, especially their use in armed attacks have been a long-standing problem of religious systems. What weapons may be developed? Is their use ethical? Namely, starting and conducting a war, or the behaviour to be followed in a war do not have only technical and law-controlled frameworks. As religious communities form integral parts of a society, they have the right to establish ethical rules regarding starting a war, and the tools and actions to be applied in a war. In view of their tradition and teachings they evaluate ethical dilemmas which arise either from the side of new technical instruments, such as remote-controlled drones able to spy or strike without a crew, or from the side of new security phenomena, such as private military forces, asymmetric wars and terrorism. [1] The attitude of religions requires conscientious, ethical and rarely canonical liability from religious communities. The value of a religious community's reflection is not given by its power gained in secular law systems or the reaction of political leadership. Equipment and challenges are changing, but the principles and ethical norms of religious communities have actually remained the same. Regarding the question of “drones” the Catholic Church does not have any official teaching yet. There are opinions and initiatives, but they are far from being fully formed resolutions. At the same time, there should be official church guidelines as church institutions and Catholic forums have formulated different points of view on the matter recently. ${ }^{4}$

\section{Machines Used in Wars and the Resolutions of Religious Communities}

It is not the first time that the ethical-moral question, whether the use of a certain weapon or process offends humanitarian conventions, has arisen in connection with drones during history. Beside considering their own ethical system, religious communities have been forced several times to make resolutions regarding weaponry and military processes. They have tried to formulate paradigms of ethical, moral behaviour for their own faithful. Not even one weapon can be considered "neutral" ethically. However, there are huge differences among different weapons and processes. It is shown by the fact that the use of certain weapons and techniques is prohibited by international law. So it is never pointless to carry out ethical investigation regarding new weapons. [3]

The effort to keep a clash of arms within certain limits appears in the teachings of several religions. [2] Hinduism condemns wars but the teaching has to be squared with the sad reality

4 The journal Ethik und Militär, which belongs to the German Catholic Military Ordinate, 1 (2014) deals with the question of drones solely. Despite the fact that the succeeding studies have widely differing opinions, the issue regarding new weapon systems is manifoldly and scientifically elaborated, which is quite unfrequent. ARKIN, C. R.: Vollautonome letale Waffensysteme und Kollateralopfer. Ethik und Militär, 1 (2014), 3-12.; GOOSE, S.: Die Notwendigkeit eines präventiven Verbots vollautonomer Waffen. Ethik und Militär, 1 (2014), 13-22.; KOCH, B.: Von Menschen und Maschinen: Was bedeutet die Robotisierung des Militärs in ethischer Hinsicht? Ethik und Militär, 1 (2014), 23-26.; MÜLLNER, K.: Ferngesteuerte Luftfahrzeuge. Maßgeschneiderter und besserer Schutz für unseren Soldaten im Einsatz. Ethik und Militär, 1 (2014), 27-35.; OETER, S.: Rechtsfragen des Einsatzes bewaffneter Drohnen aus völkerrechtlicher Perspektive. Ethik und Militär, 1 (2014), 36-41.; RUDOLF, P.: Töten durch Drohnen. Zur problematischen Praxis des amerikanischen Drohnenkrieges. Ethik und Militär, 1 (2014), 41-45.; STATMAN, D.: Drohnen, Roboter und die Moral des Krieges. Ethik und Militär, 1 (2014), 46-51.; WELLBRINK, J.: Mein neuer Kamerad. Hauptgefreiter Roboter? Ethik und Militär, 1 (2014), 52-55.; MATTHEWS, M.: Special: Stress bei Drohnenpiloten posttraumatische Belastungsstörung, Existenzkrise oder moralische Verletzung? Ethik und Militär, 1 (2014), 59-65. 
that there are wars and violence in human communities. The caste of warriors, whose task was specifically fighting, was framed to defuse the tension. On the other hand, provisions that should be followed in wars were introduced. Cavalry against cavalry and infantry against infantry were allowed to fight. Fleeing soldiers and the injured were not allowed to be killed, and those who were not involved in fights had to be respected. [2]

Buddhism elaborated a similar system. According to the original Buddhist teaching, the prohibition of killing is a supreme command. Killing a living creature deliberately was considered to be a sin. In the $7^{\text {th }}$ century, the Mahayana sect declared killing acceptable if it was for protecting the purity of the Buddhist doctrine or to prevent more deaths. [2]

Rabbinical law differentiated two kinds of wars: optional warfare, where the aim was to prevent attacks, and compulsory warfare, which meant defence against attacks. Rabbinical tradition also tried to control the weapons used in compulsory, defensive wars. It was not allowed to destroy orchards, soil and family homes. Women and prisoners of war had to be respected. A besieged town could be surrounded on three sides only, so that a way of escape could be open for the besieged inhabitants. [2]

Jihad, the holy war, is interpreted in very different ways by some Islamic schools. The interpretation ranges from the war against our own addictions to the war where the aim was is to extend Islam to the whole world, even through violent means. The restriction of weapons and processes allowed to use in wars also appears in Islamic interpretations. Killing civilians in wars was banned. Prisoners of war had to be dealt with in a humane and dignified manner. Like the Jewish approach, Islam also banned destroying orchards, settlements, churches or temples and animals. [4] Nonetheless, in all of these situations the principle of "everything was allowed that was useful for the Islamic community” predominated, which quite relativized the above-mentioned limiting factors. [5: 33] [13]

\section{The Evaluation of Launching Drones According to the Classic Glossary of a Just War}

In Catholic theology, a complex philosophical system has developed to assess wars. A few early Christian writers were even concerned about the participation in Christian wars. ${ }^{5}$ Logically, these authors did not get to the theoretical depiction about limiting available weapons in wars. This changed in the period of Constantine. [6] In 314 the third canon of the Council of Arles decreed that "Concerning those who lay down their weapons in peacetime, be it resolved that they be excluded from fellowship.” [7] According to the most common explanation of the canon, the council interpreted the military service of Christian soldiers as a compulsory civic duty. [8] There are multiple abstract interpretations of this canon as well, [9] [14] but it seems that following the literal meaning is the best. In the years of the persecutions, the military was called upon to carry out the imperial edicts. This created tensions amongst Christians in the military, so many Christian soldiers either deserted the army or they refused to obey orders. When Christianity was legalized, there was no justification for desertions. The synod underlined this fact. It reminded Christian soldiers that it was their duty to serve in the army.

5 Saint Justin, Athenagoras, Tertullian, Cyprian, Origenes, Minucius and Arnobius. 
When the "empire” became "Christian", and an existential threat to the empire was also an existential threat to Christianity, then the philosophical system of the Church had to reflect on wars and the use of war materials. At least this way the dilemmas that were looking for answers to the questions about wars and behaviour in wars was developed theoretically. The first great theorists of the doctrine of just wars were St. Ambrose and St. Augustine. St. Ambrose (337-397) developed certain principles regarding both starting a war and behaving in a war. He formulated that war could be launched after an appropriate announcement or notice. What makes it righteous to launch a war is the protection of a town or the innocent, or revenge on evil. In case of victory, mercy should be practised on victims. St. Augustine (354-430), the other great theorist of the era, did not write about war comprehensively. [10] He forms his main ideas in connection with persons and events. In his work, City of God, we can read about some forms of attitude that must be complied with. Accordingly, it is forbidden to kill the innocent, and not one of the prisoners of war can be tormented or executed.

The early decretalists like Dionysio-Hadriana, the Pseudo-Isidorian decretals of the Carolingian era, the collections of Burchard of Worms, Anselm of Lucca (eleventh century) and the Decretum and Panormia of Ivo of Chartres (in the early twelfth century) did not create a system about just war. [11: 55] They simply followed the concepts of scholars from the first Christian centuries especially the theory of Saint Augustine. The compilation of Gratian, the Concordia Discordantium Canonum had a huge influence on later canon law. His references to war and military service can be found in various passages of his work. He follows the general concept of other Christian theorists that war has to be either just or the final resort. The goal of every single war is to re-establish peace. Gratian also emphasizes the importance of the just behaviour of warriors. Moreover, according to him, pilgrims, clerics, monks, women and the unarmed poor cannot become targets in war on pain of excommunication and anathema. The compilation of Gratian became very influential, but it does not contain a single passage regulating the use of weapons. Supposedly, Gratian may have believed that if a war was necessary and just then the use of every weapon was permissible.

On the other hand, some ecclesiastical movements of the era tried to regulate the field of weapon usage when they prohibited some weapons which they classified as deadly. This can be traced back to the $29^{\text {th }}$ canon of Second Lateran Council, where they declared: "We forbid under penalty of anathema that that deadly and God-detested art of stingers and archers be in the future exercised against Christians and Catholics.” [11: 69-70] Interestingly Gratian omitted this passage from his compilation, but the later compilers have included this prohibition in their works. However, other decretalists, like the Compilatio Prima and the Gregorian decretals remained faithful to the concept of Gratian and did not write anything about limiting the use of certain weapons.

A more comprehensive elaboration of the just war's doctrine took place in Scholastic theology. Although several important contemporary philosopher-theologian authors reflected on the question, the elaboration of the doctrine is tied to St. Thomas Aquinas (1225-1274). In his scholastic school St. Thomas Aquinas improved the Augustinian doctrine of war or just war in three main directions:

- the right to launch a war: jus ad bellum (the rightful reason, the war is the last step, the rightful intention, the authority, the chance of a successful war and proportionality); ${ }^{6}$ [12]

The author emphasizes several times that the idea of the "just war" has remained theoretical and philosophical. 
- the rules of warfare, namely what can and what cannot be done in a war: jus in bello (trying for the least possible victims, keeping proportionality, differentiating "legitimate” military and non-military targets);

- the rules of settling post-war status: jus post bellum.

The question of instrument use belongs to the category jus in bello. Therefore, according to classic terminology, the ethical aspects of using new weaponry should be discussed in this category. [15] Special ethical research has been built recently on the applicability of UAV (Unmanned Aerial Vehicle), namely drones. ${ }^{7}$ [16] The original application of UAVs, the intelligence, has brought up some ethical questions, as new instruments applied in the field of intelligence have always carried moral, even legal dilemmas. (Let us think of secret information gathering.) However, the real ethical challenges are those UAV instruments that provide attack capability. [17]

From the view of the Catholic Church, scholastic categories can be partly applied. [18] The question is - in the use of UAV instruments - to what extent it is possible to take into consideration the old aspect: the difference between fighting and non-fighting participants. Reports appear daily on those civilian victims who lost their lives in UAV attacks. The data mentioned in the reports are so different from one another that it is not worth getting involved in a "data war". US authorities are trying to lessen this number. On the other hand, data from "leaks" shows them to be not only excessive but also uncontrollable. [19] The White House used to publish an annual report on how many people died or were wounded in drone attacks. in 2013, the publication of the data of Afghan drone attacks stopped, and also the accessibility of previously published information was withdrawn. According to Pakistani sources, the number of victims is a bit higher. Human rights organizations are trying to find out rather than reveal the number of civilians who have died in UAV attacks. [20] There can be victims of inaccuracy and failure not only because of launching UAV instruments. The real question is, to what extent the aspect of classic differentiation is considered. According to certain analyses, UAV instruments are able to eliminate the target with extreme accuracy. On the other hand, it has to be taken into consideration that these actions take place in grounds where al-Qaida and other radical groups are strong, and tribe leaders, families give shelter to the members of terrorist groups. In these circumstances it is not easy but impossible to differentiate the target persons. Therefore, some analyses call the attention to the psychological effects that reach the population in an UAV raid. So, even though terrorists are the targets, the observation of terrorists and the presence of drones can terrorize families and children, even the population. [21]

However, confused situations and inaccurate data favour terrorists who exaggerate the number of victims to recruit new members easily. Lots of people are afraid that the use of drones does not only results in finishing war sooner in territories in crisis, but because of the propaganda many of the young take action against that "western" power which "uses killer robots unmercifully”. [22]

The sortie of UAVs can be analysed from the side of proportion. According to the traditional aspect of a rightful war, violence in war can be used only to that extent that advances the successful finishing of a war. Some approaches state that the use of UAVs — due to the dis-

Peter Lee (former chaplain) and Alex Leveringhaus have been studying the ethical attitude of applicability of drones for years. 
tance between the machine and its operator-results in disproportion. The intense destruction and the above mentioned civil victims do not reflect the principle of proportionality either. Some people doubt whether this 'risk-free' warfare can be called warfare or rather maintaining safety and security, in which one party undertakes considerably less risk. [23: 47] When evaluating new technical instruments, it has to be considered that military leaders will, by definition, approve the use of such instruments that will lead to greater success and fewer human victims on their side. [3]

The war between the living and the non-living emerges as a new question. The machines used today are not independent from humans. They are better termed RPA (Remotely Piloted Aircraft). [17: 2] It is emphasized that they are not robots in the strict sense of the word, but ultimately human operated machines with robotic elements. [24] In an operation there are elements that are performed by these machines autonomously (landing, taking off, some flight operations) but there are humans behind the operation whose role and responsibility will remain. [25: 11] In theory, we can play with the idea whether there will be 'martial' robots operating without any human control that can destroy human life, but this is not the case here. Regarding this idea, some authors note that in this case the ultimate responsibility is of those who develop robot control softwares, and of those politicians who have to make legal and ethical rules which give a framework for the use of automated weapons. [26: 3-5] On the contrary, others say that fully automated martial weapons contravene fundamental ethical principles, so their mere development should be banned. [27] Aside from the authors' opinion, the fact is that the decision-making environment has changed compared to classic warfare, which has advantages and disadvantages. As physical presence promotes the perception of the significance and reality of the situation, remote controlling results in greater calmness and more sober decision-making. However, it is a common criticism that distance can generate the so-called video-play syndrome or brutality/apathy towards victims. Truth is, brutality towards victims can happen both using remote-controlled instruments or during the execution of a classic action. ${ }^{8}$ [28] What is more, some analysts note that the stress surrounding a pilot or a soldier whilst using the UAVs do not result in thoughtless decision and it does not play any role. [29]

According to the classic view, war should be considered the last step. It is only acceptable to engage in warfare if no other sanction leads to results. The use of drones has developed the possibility for political leaders not to reckon with victims from their own side. Therefore, some critics say that it can easily happen that politics will use the war-level of violence soon. According to some Catholic explanations, covert operations and targeting strikes belong to the category of preventive sanctions, just like diplomatic tools, international and economic pressure, blockade, etc. [30] These tools serve the avoidance of using major military forces. So, it would be right to consider that the targeted use of UAVs with attack capability can fit the avoidance of using major military forces.

Furthermore, there is no crew that can be killed when using a UAV strike, however the number of casualties or injured can be much higher on the other side. [31: 130] Others say that as commanders are responsible for their own soldiers, it is not a possibility but an obligation for them to use instruments—-such as drones — that provide greater security for soldiers.

8 The author has indicated the extreme, human war-time reactions of which soldiers are not excluded either. The consequences are the indifference towards human suffering or the development of cruelty. 
It is the moral obligation of political and military leaders to provide soldiers as secure situations as possible. UAVs are said to provide this security. [32]

Finally, it is also true that a serious industry that makes considerable profit has been established building drones, especially their armed versions. [29] So this segment must be considered as well when evaluating these weapons morally.

According to the Catechism of the Catholic Church (2316) "The production and the sale of arms affect the common good of nations and of the international community. Hence public authorities have the right and duty to regulate them. The short-term pursuit of private or collective interests cannot legitimate undertakings that promote violence and conflict among nations and compromise the international juridical order.” [33] The ecclesiastical document forms general views regarding excessive weapon development and economy. This applies to the new UAV weapon system as well. It is a fact that UAVs are cheaper than conventional airplanes. New weapon systems always bring along a never-ending spiral: the technology that defends against these systems and later the development of instruments that exceed the technology of the defence system. [34] Naturally, it has a considerable economic aspect.

However, according to some analyses, the American drone monopoly may break on account of the profit priority of the sector. The fact that in some years substate organizations or terrorists will also possess attack capable UAV systems, cannot be excluded. [35] These threats must not be ignored, ${ }^{9}$ which opens a new era regarding the "proliferation" of weapons of destruction.

\section{The Reflection of the Catholic Church on the Use of Remotely Controlled Weapons}

The question on the use of remotely controlled weapons is not new in the reflection of the Catholic Church. In 1139, the Second Lateran Council dealt with the use of crossbows and catapults. The anxiety of the council fathers' was derived from the belief that new weapons would change knightly virtue, in which it was an important requirement of combatants to fight on foot. Therefore, the council came to the decision: "We forbid under penalty of anathema that that deadly and God-detested art of stingers and archers be in the future exercised against Christians and Catholics."10 [37] Later a more dangerous weapon appeared: the longbow, which was capable of launching at least twelve arrows, contrary to the three arrows of the crossbow. Since the $11^{\text {th }}$ century this weapon had wrought havoc on battlefields, the Church had to make a declaration on the question in official forums. It is also operative in conciliar provisions that the principle regarding criminal legislation must be closely interpreted. As the text uses the expressions "Christian" or "Catholic", the provision did not have to be extended to non-Christians, according to the general explanation. [38] Regardless of the conciliar measures, Christians deployed these weapons against each other. They did not want to give up the benefits of these effective weapons. The inefficiency of the provision was shown by the fact that in 1234, nearly a century later, Pope Gregory IX strengthened the enforcement. It was as inefficient as the conciliar provision.

\footnotetext{
9 Hezbollach, which operates in Lebanon, has drones as well. [36]

10 “Artem illam mortiferam et odibilem ballistariorum et sagittariorum adversus Christianos et catholicos exerceri de caetero sub anathemate prohibemus.” [37]
} 
However, the council and apostolic prohibition proposed a serious canonical explanation. ${ }^{11}$ On the one hand, canonical schools studied whether the apostolic prohibition referred to the philosophical category of the "just war" only, or did it extend to all armed fights. That is, whether the use of these weapons is permissible from the party which conducts-according to the Christian teaching - a just war. Or rather, the question arose again in some cases: was the prohibition operative if the opposing party was non-Christian? Though the default values of the conciliar decision - that the above-mentioned weapons were prohibited only against Christians - lived on, sometimes new phrasing occurred, which was against the general understanding. Serious canonical explanations developed in reference to the punishment prospected by the synodical provision. Excommunication is "self-supervening”, so the legal effect takes place without any other Church measure or the ecclesiastical authority has to declare it subsequently together with its direct legal sanctions. As the conciliar provision does not give an obvious guideline in this field, the canonical explanation played the major role. In comparison with UAVs, it is worth mentioning some early authors' opinion as to how they saw the reason for that rigorous regulation. The penitential manual Quia non pigris, which devotes a whole chapter to the question of catapult operators, sees the reason for the rigorous prohibition as "these weapons kill extremely quickly". [39: 40] Henricus de Segusio (Hostiensis) explains the prohibition: catapults and crossbows are prohibited because they have excessive toughness and unexpected lethal effects. He even adds that this is irrespective of the war they are used in. [39: 39] The medieval provisions and the explanations written in them are important with regard to the fact that they were studied from the scope of newer weapons, and some authors-as analogia legis-extended them to canons and other firearms. [39: 51]

The language of the $20^{\text {th }}$ century ecclesiastical documents has changed a lot. The statement dealing with the moral-ethical assessment of modern weapons has more a teaching than criminal attitude. Regarding UAVs, ecclesiastical utterances concerning weapons of mass destruction (WMD) are significant. On one hand, we can see some gradual approach with which official ecclesiastical forums evaluate the ethical and moral dimensions of new weapon systems. On the other hand, UAVs raise similar ethical questions in many aspects: remote control, civilian victims, destructive power, etc. Therefore, by analogy some conclusions and principles can be referred to UAV systems, too. The appearance of WMDs made the Catholic Church adjust its reasoning on "just war" to the conditions created by new weapon systems. Today such a change of era is taking place, which makes it justified to think over old concepts.

By the '80s it had already become obvious that nuclear weapons could not create that degree of deterrence that had been hoped for. Disarmament programs and international debates inspired the Catholic Church to contemplate newer reflections. [40] Pope Saint John Paul II's speech, held in the UNO in 1982, about the existence and use of nuclear weapons determined the position of local episcopal conferences on this question. The Pope thinks that "In current conditions 'deterrence' based on balance, certainly not as an end in itself but as a step on the way toward a progressive disarmament, may still be judged morally acceptable. In his opinion, expressed to diplomats in 1982, he noted that the last goal, which cannot ever be lost sight of, is total nuclear weapon disarmament.” [41] After

11 Comprehensive review to some medieval authors' explanations: [39] 
the Pope's and the Holy See's declaration, some episcopal conferences concerned also made declarations. Among the utterances of episcopal conferences, the circular of the American Episcopal Conference (published in 1983) is extremely significant. [42] Against extremely pacifist views, the document is a down-to-earth statement with realistic social approaches, which forms points of view that can be considered regarding the use UAVs. Not only does it confine to establish general principles, but it also conducts ethical assessment. [40] The document-in a separate subchapter and in the light of new instruments - studies the concept of jus in bello. According to the circular, internationally banned weapons cannot be used, the principle of proportionality and the saving of non-combatants must be respected. The document admits that it is not easy to determine military targets in a modern war, but the destruction of civil targets — such as children, schools, hospitals, the sick, the old, non-military workers or agricultural workers - cannot be allowed. Actions cannot be taken against non-combatants, not even if the action has any retaliatory measures. On this question it formulates, also on the level of the individual's conscience, that a command that is against the most fundamental ethical and moral norms cannot be executed by a Christian. Regarding new weapon systems, it also has a significant wording, as it declares that the questions of nuclear weapons are not only political and military ones, but they have primal ethical significance, too. It is also true regarding UAV systems.

The 1994 Catechism of the Catholic Church (CCC) formulates significant principles on the level of the universal church. The document (2309) deals with the question of launching a war. As a matter of fact, it summarizes the traditional teachings on the discipline of the rightful war. ${ }^{12}$ CCC $(2312,2313,2314)$ studies the compulsory behaviour in a war. CCC (2312) also repeats the principles of the Second Vatican Council: the Church and the human reasons propagate the unchanged validity of the moral law during armed conflicts. "Nor, by the same token, does the mere fact that war has unhappily begun mean that all is fair between the warring parties.” [44: 79] It is not allowed to torture, kidnap or force anybody. CCC (2313) specifically protects non-combatants. "Non-combatants, wounded soldiers, and prisoners must be respected and treated humanely.” [43: (2313)] CCC (2314) is similar, and repeats the teaching of the Second Vatican Council. [44: 80] These "general" ecclesiastical utterances are significant regarding the use of UAVs. While it is true that when these documents came into existence, the question of using UAVs did not come up, but by analogy both synodical documents and the utterances of CCC are relevant regarding new weapon systems, too. The destruction of the population of cities or greater territories without any distinction is prohibited and considered to be a serious sin by the ecclesiastical documents. Regarding nuclear, biological or chemical weapons, the documents mention

12 "The strict conditions for legitimate defence by military force require rigorous consideration. The gravity of such a decision makes it subject to rigorous conditions of moral legitimacy. At one and the same time:

- the damage inflicted by the aggressor on the nation or community of nations must be lasting, grave, and certain;

- all other means of putting an end to it must have been shown to be impractical or ineffective;

- there must be serious prospects of success;

- the use of arms must not produce evils and disorders graver than the evil to be eliminated.

The power of modern means of destruction weighs very heavily in evaluating this condition.” [43: (2309)] 
that there is a much greater opportunity for the use of these weapons in modern wars. So today the list of the weapons of these documents should contain UAV systems as well. ${ }^{13}$

John Paul II gave a complex statement about the nature of armed conflicts on the World Day of Peace in 2000. [45] Here the pope classified small-calibre weapons and so-called "light" arms as the most dangerous weapons on Earth partly because these armaments are responsible for the most casualties in conflicts and partly since it is almost impossible to block their smuggling into crisis zones. The pope added that the civilian population suffers the most tragically from measures intended to disarm an aggressor.

\section{Ecclesiastical Utterances Regarding UAV Weapons}

As regards to UAV weapons no official opinion has been declared by the Holy See, but some Catholic moral theologians and Catholic research institutions have dealt with the question.

Archbishop Silvano M. Tomasi, UN delegate of the Holy See, summarized his opinion in a letter. It says:

1. The technology may lower the threshold of conflict, making it seem more attractive to enter into war.

2. Large populations live in constant fear of the strikes where these strikes are systematic. These people think that their own lives and property can be victims of mistaken strikes in the future.

3. It is difficult "to assess the precise impact on civilians of the use of weaponized drones".

4. When data related to the use of weaponized drones is withheld, compliance with international law, international humanitarian law and ethical standards cannot be verified.

5. Today we can speak about the proliferation of drones. There are not always ethical restrictions to use them, but non-restricted cases must be clearly set. The restriction is needed to limit the accelerating spread—“proliferation”—of drones. [46]

Archbishop Tomasi in an interview given to Radio Vatican stated that however complex machines were, they would never be able make a real ethical judgement. In the interview he said that the excessive spread of UAVs was of concern as it could spoil international relations between different countries. Bishop Tomasi's letter or the interview is confined to the most relevant points. It is obvious that the background research, which the Holy See owns in other fields, is still missing. In certain Western-European countries, where there is a culture of researching the ethical, religious, military science questions together, the ethical evaluation of UAVs is already well advanced. The utterances of the German Catholic Church, given in different forums, are notable. [47] Bishop Franz-Josef Overbeck, military ordinary has often spoke concerning the question. Since the German governmental intention was revealed-according to which Bundeswehr would be armed with attack capable UAV planes-he has set out his position in several forums. Institut für Theologie und Frieden, which works closely with German Military Ordinate, has made

13 "Every act of war directed to the indiscriminate destruction of whole cities or vast areas with their inhabitants is a crime against God and man, which merits firm and unequivocal condemnation. A danger of modern warfare is that it provides the opportunity to those who possess modern scientific weapons-especially atomic, biological, or chemical weapons - to commit such crimes. [43: (2314)] 
several analyses and background materials for the ordinary. In 2012, the ordinary already noted that the problem had to be studied from every side critically. [48] Actually, he expects the German political leadership to clarify the legal and ethical frameworks of attack capable UAV weapons. According to the ordinary, the large distance between the weapon and the operator is problematic, and he considers it to be ethically questionable to endanger non-combatants and civilians so that soldiers can be safe.

On the conference about remote controlled airplanes that was organized by Bishop Stephan Ackermann, the chairman of Justitia et Pax, and the military ordinary had the same final conclusion. At the end of the conference it was formulated again that professionally correct answers were expected from the political leadership. In a joint declaration they summarized their concerns regarding remote controlled attack capable airplanes. In their opinion, political authority — for the sake of soldiers—must clarify this question. Although the two German, Catholic philosophers, theologians are not always of the same mind, they agreed on key questions, respectively that the debate should be submitted to a broader social discussion, and the political and military leadership should give professionally correct answers. For that reason, a set of questions that should be submitted to public discussion was compiled.

Both Catholic theologians agreed that weapon systems providing safety to soldiers, such as remote controlled armed planes, can and have to be developed. However, when evaluating these weapons, we cannot be confined to stereotypes. There is truth in critical statements, of which much is true to combat aircraft, helicopters or sharpshooters as well. [49]

According to the bishop's declaration, the most important ethical question is how new weapon systems affect the ethical principle and goal of using the least possible violence. The possibility offered by drones can easily create "asymmetry" between conflicting parties, so the stronger party will sooner make use of violence. UAVs create the necessary circumstances for soldiers involved to be in greater safety, but the other party's soldiers and civil inhabitants are in greater danger due to the use of these machines. Especially, if the intelligence information which the mission is based on is not accurate enough.

Likewise, what criteria exist as the basis for the decision: when to give a lethal strike on hostile powers? Is it not an unlawful massacre, or is it the use of capital punishment without a trial?

Other German bishops occasionally made declarations regarding UAVs. Archbishop Ludwig Schick of Bamberg says that the use of armed drones can intensify violence. [50] In March, 2013, in Königsbronn-in the Reserve Army of Germany (Deutschen Reservistenverbandes) —Archbishop Robert Zollitsch stated that he was missing those clear criteria which would unambiguously define the conditions of using drones.

German bishops are of the same opinion: there should be a social discussion in this matter, and while the political leadership form their point of view regarding the obvious legal and ethical frameworks of using drones, they should take notice of the classic principle of using wartime violence as the last step. The opinion (Arbeitspapier) of the Community of Catholic Soldiers (Gemeinschaft Katholischer Soldaten) differs from that of the Pope's. According to their view, the Bundeswehr should have strike capable UAV systems but, on one hand, they cannot be used for targeted destruction practiced by the USA, on the other hand, German soldiers should get clear and unambiguous training about the ethical and legal frameworks of UAV deployments. Furthermore, the document itself notes that violence can only be the last step, and the number of civil victims should be minimized. [47: 11] 
American Catholic Church leaders especially feel involved in the matter because of the international involvement of the United States. In this case both Catholic theologians and official church forums answer the ethical dilemma of the application of UAV systems. [51] Their doubts are similar to the already introduced critical views - namely the threat of civil inhabitants- [52] hence there is no possibility of selecting targets. ${ }^{14}$ They note that the drone program, launched under the Bush presidency, has increased significantly under the Obama administration. [53] Furthermore, the deployment of drones did not even shorten military missions. Terrorist cells regenerate quickly, they are able to recruit new members and replace leaders with new ones. [54]

The Iustitia et Pax (IUPAX) commission of the United States Conference of Catholic Bishops (USCCB) wrote letters to several United States congressional committees. In the letter IUPAX summarized the doubts that can occur regarding armed UAVs. They emphasize that everybody has the right to protect themselves in self-defence, but this principle does not give the opportunity to use any means of weapons without limitation. On the other hand, the letter lays down an important statement. The principles of a just war cannot be applied to the fights against terrorists outside the "battlefield.” The elements of the just war was worked out to be used in a war, not outside the battlefield in anti-terrorist actions. If we used the same categories for terrorists (as substate participants), philosophically we would raise them to the level of state participants'. Therefore, philosophically, anti-terrorist movements cannot be called at war. However, there are questions on using certain weapon systems, as follows using UAV systems. The American IUPAX finds it offensive that UAV systems do not make any difference but they consider each armed man over a certain age to be an enemy. The letter quotes the Compendium of the Social Doctrine of the Church: "a preventive war without clear proof that an attack is imminent cannot fail to raise serious moral and juridical questions.” By analogy, the letter states that a lethal strike without obvious evidence to the fact that the people attacked are really terror threats raises moral dilemmas.

\section{Conclusions}

Throughout history the development of military appliances has always involved ethical and moral questions. Religious communities, as integral parts of the society, felt impelled to speak. The Catholic Church needed time to evaluate each weapon system. However, it is obvious that there are periods in history when the church, both universal and particular, has to make a declaration on using certain weapons regarding ethical and moral perspectives. It is true that the evaluation should take into consideration the eternal moral verities, but on the other hand, it can not ignore neither military, nor political arguments. Regarding the use UAV weapons, their military and political benefits cannot be ignored either. (Little fuel consumption, cheaper maintenance, strategic benefits, greater safety of soldiers, etc.) [55] The moral and ethical questions which these technologies bring forward have to be exposed beside these benefits. (Mental problems, fear, greater threat to civil inhabitants, asymmetry, fight between human and machine, video game effect because of the distance, etc.)

14 The study mentions Osama bin Laden's elimination: it was executed by special forces and not with remote controlled planes. [51] This opinion is only partly true, as it was important to make sure personally of the success of eliminating the terrorist leader. 
The Catholic Church does not possess a universal resolution on the question. On the highest level Archbishop Tomasi-UN delegate of the Holy See-has spoken about the use of drones so far, in a rather critical tone. The utterances of the German Church are notable locally as they model the dialogue that the Church should hold with each segment of society based on the principles of the Second Vatican Council. The utterances of the American Catholics, which try to square international tendencies with the tradition of the Catholic Church, are also notable. Due to the American involvement, it is the most affected community.

The Catholic Church has already established severe official resolutions regarding nuclear and biological weapons. Hopefully, a resolution which is coherent with ecclesiastical traditions but also takes political tendencies and military technologies into consideration will be formed in this field in time.

\section{References}

[1] RESPERGER I., TÚRI V.: A terrorizmus és az aszimmetrikus hadviselés pszichológiai aspektusai. Repüléstudományi Közlemények, 2 (2010), 1-16.

[2] SOMFAI B.: Háború és béke a Katolikus Egyház tanításának fényében. Szeged, 1992. http://web.295.ca/gondolkodo/talalkozo/irasok/Somfai1HU04.html (Downloaded: 1004 2017).

[3] Bundeswehr und Kampfdrohnen. Deutschlands volle Drohnung. www.taz.de/!126091/ (Downloaded: 2605 2014).

[4] Dzsihád = Szent háború? Iszlam.com. http://iszlam.com/iszlam-az-elet-vallasa/iszlamalapismeretek/item/54-dzsihad-szent-haboru (Downloaded: 0306 2014)

[5] FODOR P.: A dzsihád íze: A szent háború az iszlámban és a 14-17. századi Oszmán Birodalomban. Historia, 30 (2008).

[6] SMITHER, L. E.: Rethinking Constantine History, Theology, and Legacy. Eugene, OR: Pickwick, 2014.

[7] The Canons to Sylvester from the Council of Arles (A.D. 314). www.fourthcentury.com/ arles-314-canons-to-sylvester/ (Downloaded: 0905 2017).

[8] HARNACK, A.: Militia Christi: Die christliche Religion und der Soldatenstand in den ersten drei Jahrhunderten. Tübingen: J.C.B. Mohr (Paul Siebeck), 1905.

[9] LECLERCQ, H., HEFELE, K., MICHEL, A.: Histoire des conciles d'après les documents originaux. Paris: Librairie Letouzey et Ané, 1952.

[10] MARCUS, A. M.: Saint Augustine’s Views on the “Just War”. In. SHEILS, W. J. (Ed.): The Church and War. Hoboken: Blackwell, 1983.

[11] FRUSSEL, F.: The Just War in the Middle Ages. Cambridge: Cambridge University Press, 1975.

[12] SZIGETI P.: A nemzetközi jog és az igazságos háború eszméjének fejlődése. www.ajk.elte. hu/file/SzigetiPeter-NemzetkoziJog.pdf (Downloaded: 2605 2014).

[13] MÜHL, B.: Faszination Dschihad von Sinnleere und Todesliebe: Von Sinnleere und Todesliebe. Communio, 46 (2017), 142-146.

[14] MARROU, H.: Christiana tempora: Mélanges d'histoire, d'archéologie, d'épigraphie et de patristique. Collection de l'École française de Rome, 35. Roma: École française de Rome, 1978.

[15] The German Bishops: Soldiers as Servants of Peace: Statement on the Status and Tasks 
L. UJHÁZI: Further Ethical Challenges in Military Science from the Perspective of the Catholic Church:...

of Soldiers in the Federal Armed Forces. Bonn: Secretariat of the German Bishops' Conference, 2006, 6.

[16] The Bureau of Investigative Journalism, 14. 04. 2014. Drones Podcast: An Ethics Special. www.thebureauinvestigates.com/stories/2014-04-14/drones-podcast-an-ethics-special (Downloaded: 0905 2017).

[17] DUDÁS Z., RESTÁS Á.: Nemzetközi példák az UAV repülés emberi tényezőit érintő jogi szabályozásra az RPAS 2012 konferencia tapasztalatai alapján: Kockázatkezelési elvek megvalósulása a szabályozásban. Repüléstudományi közlemények, 243 (2012), 7-10. www. repulestudomany.hu/folyoirat/2012_3/2012-3-01-Dudas_Z-Restas_A.pdf (Downloaded: 20 05 2014).

[18] WILLS, G.: What is a Just War? Arguing About War by Michael Walzer. New York Review of Books, 5118 (2004). www.nybooks.com/issues/2004/11/18/ (Downloaded: 2005 2014).

[19] ROMÁSZ A.: WikiLeaks: Több mint százezer civil áldozat. Kitekinto.hu, 26. 10. 2010. http://kitekinto.hu/archivum.php?kulcsszo=Rom\%C3\%A1sz\%20Andrea\&szerzo=1\#. U5ldLXY7jXQ (Downloaded 1206 2014).

[20] Hány civil áldozata van a drónoknak? Kitekinto.hu, 31. 10. 2013. http://kitekinto.hu/ europa/2013/10/31/hany_civil_aldozata_van_a_dronoknak/ (Downloaded 0206 2014).

[21] SHIMA, T., RASMUSSEN, S.: UAV Cooperative Decision and Control. Philadelphia: Society for Industrial and Applied Mathematics, 2009.

[22] World Churches Condemn Use of Drones. Independent Catholic News, 13. 02. 2014. www. indcatholicnews.com/news.php?viewStory=24156 (Downloaded: 1006 2014).

[23] VARGA A. F.: A drónok mint a kockázatmentes hadviselés eszközei. Hadtudományi Szemle, 62 (2013), 44-58.

[24] LEVERINGHAUS, A.: What's so Bad About the Killer Robots? www.surrey.ac.uk/politics/ files/cii/Leveringhaus_Surrey\%20presentation.pdf (Downloaded: 1505 2014).

[25] BASTIAN, B.: Roboter am Abzug: Sind Soldaten ersetzbar? Auftrag - Gemeinschaft Katholischer Soldaten, 53 (2013).

[26] ARKIN, C. R.: Vollautonome letale Waffensysteme und Kollateralopfer. Ethik und Militär, 1 (2014), 3-12.

[27] GOOSE, S.: Die Notwendigkeit eines präventiven Verbots vollautonomer Waffen. Ethik und Militär, 1 (2014), 13-22.

[28] HARAI, D.: Érték, teljesítmény, siker: Tanulmányok, esszék a katonapedagógia, a katonai antropológia köréből. Budapest: Zrínyi Kiadó, 2013.

[29] FIEDERSDORF, C.: Distant Death: The Case for a Moratorium on Drone Strikes.

The Atlantic, 14. 11. 2013. www.theatlantic.com/politics/archive/2013/11/distant-death-thecase-for-a-moratorium-on-drone-strikes/281471/ (Downloaded: 1505 2014).

[30] Just War Doctrine. www.catholicleague.org/just-war-doctrine/ (Downloaded: 1006 2014).

[31] CSENGERI J.: A dél-szláv légi háború: A NATO légi háborúja a dél-szláv válság megoldása érdekében 2. Repüléstudományi Közlemények, 251 (2013), 126-133.

[32] STRAWSER, B. J.: Moral Predators: The Duty to Employ Uninhabited Aerial Vehicles. Journal of Military Ethics, 9 (2010) 343-344. DOI: https://doi.org/10.1080/15027570.2010.536403

[33] Catechism of the Catholic Church.

[34] VÁNYA L.: Hogyan védekezzünk a drónok ellen? Repüléstudományi Közlemények, 252 (2013), 255-261. 
L. UJHÁZI: Further Ethical Challenges in Military Science from the Perspective of the Catholic Church:...

[35] Terjednek a drónok: Visszaüthet a megelőző csapás gyakorlata. Háború Múvészete, 07. 11. 2011. www.haborumuveszete.hu/rovatok/fegyverek/repulok/terjednek_a_dronok_ visszauthet_a_megelozo_csapas_gyakorlata/ (Downloaded: 1705 2014).

[36] SINGER, P. W.: Wired For War: The Robotics Revolution and Conflict in the $21^{\text {st }}$ Century. London: Penguin Press, 2009.

[37] II. Lateran Council.

[38] Ördögi szerszám Isten szolgálatában. Tudtad.com, 25. 04. 2014. www.tudtad.com/2014/04/ ordogi-szerszam-isten-szolgalataban.html (Downloaded: 2805 2014).

[39] ERDŐ P.: Az íjászok és hajítógép-kezelők büntetése: Adalékok a kánonjogi esetmegoldás módszeréhez a kései középkorban. Magyar Sion, 2 (2008) 23-58.

[40] SOMFAI B.: Az Amerikai Püspöki Konferencia pásztorlevele a békéről. http:// tarsadalomformalas.kife.hu/az-amerikai-puspoki-kar-pasztorleve-a-bekerol/ (Downloaded: 1206 2015).

[41] Pope JOHN PAUL II.: Messagio ai diplomati. L'Osservatore Romano. 05. 01. 1988.

[42] National Conference of Catholic Bishops: The Challenge of Peace: God's Promise and Our Response, a Pastoral Letter on War and Peace. Washington. NCCB, 1983. www.usccb.org/ issues-and-action/human-life-and-dignity/war-and-peace/nuclear-weapons/upload/statementthe-challenge-of-peace-1983-05-03.pdf (Downloaded: 1206 2014).

[43] Catechism of the Catholic Church.

[44] Pope PAUL VI: Pastoral Constitution on the Church in the Modern World. Gaudium et spes. Vatican: Second Vatican Council, 1965. www.vatican.va/archive/hist_councils/ii_vatican_ council/documents/vat-ii_const_19651207_gaudium-et-spes_en.html (Downloaded: 1206 2014).

[45] Pope JOHN PAUL II: Message of His Holiness Pope John Paul II for the Celebration of The World Day of Peace. 01. 01. 2000. http://w2.vatican.va/content/john-paul-ii/en/ messages/peace/documents/hf_jp-ii_mes_08121999_xxxiii-world-day-for-peace.html http:// tarsadalomformalas.kife.hu/az-amerikai-puspoki-kar-pasztorleve-a-bekerol/ (Downloaded: 1206 2017).

[46] FIEDERSDORF, C.: The Holy See: Lethal Drones Pose Urgent Ethical Issues. The Atlantic, 25. 11. 2013. www.theatlantic.com/international/archive/2013/11/the-holy-see-lethal-dronespose-urgent-ethical-issues/281794/ (Downloaded: 1505 2014).

[47] GERHARD, A. von: Streit um Kampfdrohnen: Die positionen der beiden grossen Kirchen. Auftrag - Gemeinschaft Katholischer Soldaten, 53 (2013), 9-10.

[48] HEVERKAMP, C.: Militärbischof: Verteidignugsminister sollte Einsatz von Drohnen „hochkritisch prüfen”. Neue Osnabrücker Zeitung, 2012. 08. 31.

[49] WIEGOLD, T.: Katholische Bischöfe fordern ethische Diskussion über bewaffnete Drohnen. 05. 02. 2013. http://augengeradeaus.net/2013/02/katholische-bischofe-fordern-ethische-diskussion-uber-bewaffnete-drohnen/ (Downloaded: 2405 2014).

[50] BUCHSTEINER, R.: Umstrittene Aufrüstung, Bundeswehr will Kapfdrohnen anschaffen: Kritik von Opposition und Kirchen. Ruhr Nachritten, 2013. 01. 26.

[51] DARLING, A.: Catholics See Moral Complications in Drone Usage. www. catholicnewsagency.com/news/catholics-see-moral-complications-in-drone-usage/ (Downloaded: 0526 2014). 
L. UJHÁZI: Further Ethical Challenges in Military Science from the Perspective of the Catholic Church:...

[52] STAFFORD, S. C.: I Met a 16-Year-Old Kid. 3 Days Later Obama Killed Him.

The Guardian, 06. 14. 2012. www.alternet.org/story/155723/i_met_a_16-year-old_kid._3_ days_later_obama_killed_him?page=entire (Downloaded: 2605 2014).

[53] Department of Justice, Peace and Human Development, Office of International Justice and Peace: Background on Armed Drones. January 2014. www.usccb.org/issues-and-action/ human-life-and-dignity/war-and-peace/upload/background-on-armed-drones-2014-01.pdf (Downloaded: 2805 2016).

[54] ODDIE, W.: A Moral Theologian Defends the 'Surgical'Use of Drones to Assassinate Terrorist Leaders: But is Their Use Really Intended to Minimise Civilian Deaths? www. catholicherald.co.uk/commentandblogs/2012/11/20/a-moral-theologian-defends-thesurgical-use-of-drones-to-assassinate-terrorist-leaders-but-is-their-use-really-intended-tominimise-civilian-deaths/ (Downloaded: 2805 2016).

[55] Gutes töten? Katolisch.de, 01. 23. 2013. www.katholisch.de/de/katholisch/themen/ politik/130122_drohnen_bundeswehr_krieg.php (Downloaded: 2805 2014). 